\title{
In praise of students as supervisors
}

\author{
By Mary Nagel \\ Periodicals Librarian \\ St. Cloud State University
}

and Jeanne Molloy

Library Technician

St. Cloud State University

\section{Cooperation is the key to success.}

ibrary literature describes a number of well-organized student worker programs. Some academic libraries interview potential student employees, hiring and evaluating applicants according to guidelines established by the library. Some fortunate libraries have graduated pay scales so they can offer promotions, greater job responsibilities, and more money to more experienced students. Other libraries use graduate assistants in a quasi-supervisory role to provide valuable training and support.

Unlike more fortunate institutions, the Periodicals Section of St. Cloud State University's Learning Resources Services does not have a centrally organized student worker program. Nor is it set up to interview, screen, or select student workers, or to offer them promotions on a graduated pay scale. Though graduate assistants work throughout the library, their duties do not include trainingor supervising student workers.

Approximately 30 students are arbitrarily assigned to the Periodicals Section during the first week of fall term. Student workers who are new to the Periodicals Section and to library work in general are suddenly thrust into a patron-centered service environment.

\section{A comedy of errors}

In the past, student workers reported to the library technician, who attempted to train each individual on the job. This "crash" program was unfair to the workers and to the faculty and student patrons they were supposed to serve. The urgent attention these patrons required was the very thing that interrupted any sane, step-by-step approach to training. Sometimes the student trainee was the only help available to staff the service desk. Students had to be able to function immediately in the most routine and visible task - circulation of periodicals. They had to demonstrate some self-confidence and composure in order to cope with a variety of requests from patrons, who can be demanding and abrasive. In effect, they had to train themselves. As a result, their knowledge of the department's policies and procedures was always partial and incomplete, and they fumbled along by trial and error. Library patrons received inconsistent service and doubted the professionalism of the entire section. Since students were trained so sporadically, they felt inadequate to handle their duties, and their morale was low.

\section{A midsummer night's dream}

By the summer of 1988 , it was clear that something had to be done to improve training. A suggestion to select experienced student workers for use as training supervisors was at first dismissed, because of the assumption that students would never accept additional responsibility without additional compensation. With a fixed student wage at SCSU, no one could look forward to any increased hourly pay. But the idea of student supervisors was so attractive that the decision was made to give it a try.

In fact, not only were the selected students willing to assume more responsibility, but they appeared to relish the chance to delegate work to their peers and to prioritize work assignments in the busy Periodicals Section when regular staff mem- 
bers were not present. For one thing, they seemed to want to share their expertise with others. To be able to include a "promotion without pay" increase on their resumes was another important consideration.

Late in the summer, staff members and four experienced, mature, and responsible students devised a checklist of training procedures and set up a tentative training schedule to break in new student workers. The following September, each new worker signed up for a training session before reporting for a work assignment. Workers first met in small groups with their student supervisor. Then, during their first week of work, a second session provided more in-depth training. The student supervisors followed the checklist and explained the appropriate procedures in each assigned area. Students were paid the hourly wage during this training (about an hour) and then began their duties working alongside an experienced student who helped them ease into the job. Each worker was also expected to read and understand the Student Worker Manual, which spelled out all the procedures.

\section{All's well that ends well}

What had been chaotic now became orderly. The practical know-how of the experienced students was a great help to the new students, who made fewer errors and learned their jobs more quickly than before. Periodic evaluations of the new plan refined the training procedures, and supervisors and their trainees responded favorably to the new program. At the end of the first year's trial, the training program had proved successful and was given a degree of permanency.

The following year, the number of student supervisors was doubled. As more students took on supervisory functions, their teaching example and their resourceful problem-solving proved valuable, and they gradually gained respect and credibility in the eyes of other student workers. Student supervisors communicated freely with full-time staff and small problems were discussed and solved before they became larger. Staff members grew to rely on experienced students for various projects that called for their more extensive knowledge of library procedures. Student supervisors made many suggestions that improved the entire operation. When student supervisors were scheduled for evening or weekend hours, they proved very responsible in solving the inevitable problems that crop up during those times.

The new program was easy to design, implement, and evaluate. Its success is due in large part to the cooperation between the periodicals librarian, the library technician, and the student supervisors, who have shown that they can be motivated by something other than pay increases. Their need for respect is fulfilled naturally when they have an opportunity to participate in the improvement of library services. Along with contributing new ideas and strategies in training student workers, student supervisors have more authority to report unacceptable work habits of those they supervise.

Student supervisors evaluate the program positively, reporting a clearer sense of personal pride and self-worth on the job. The opportunity to affect policy and procedures provides them with an outlet for their ideas and concerns. In addition, they are challenged to develop supervisory skills, build selfconfidence, and improve their human relations skills. The response of library patrons is indirect; however, fewer complaints are registered about service and the performance of student workers. Because of more thorough and more consistent training, student workers have fewer questions regarding library service and the procedures they are asked to follow. Accordingly, morale has greatly improved, and student workers now service patrons with a more positive attitude. Of course, the library technician's outlook on the program is also positive, which contributes additionally to the morale of the library staff. Perhaps in knowing "How these things came about," as Shakespeare said, "You (too) shall find a benefit in this change."

\section{Call for poster sessions at the ACRL National Conference}

The National Conference Executive Committee invites you to submit a poster session proposal for the ACRL Sixth National Conference to be held in Salt Lake City, Utah, April 12 14, 1992

Poster sessions are informal presentations of unique and trendsetting programs and activities being carried out in academic or research libraries. Potential presenters of poster sessions should submit a poster session proposal form (call the ACRL office, (800) 545-2433, ext. 2516 for the form). The deadline for submitting a completed form is November 1, 1991. Send the completed form to Jean E. DeLauche, ACRL Poster Sessions, 7040 North 60th Street, \#203, Milwaukee, WI 53223.

The conference theme, "Academic Libraries: Achieving Excellence in Higher Education," will explore the major issues confronting academic libraries now. The following are the sub-themes of the conference: diversity in the academic community; the increased complexity of information resources in many formats; the research agenda for academic and research libraries; and technology and library users. 


\section{ACQUISITION PERSPECTIVES}

6. Book House is in its fourth generation of automation. Our custom software allows us the flexibility to accept orders generated through your computerized system or in the mail. Our policy is to develop a working compatibility with the automated system in your library to facilitate receiving orders, transmitting open order reports and invoices electronically.

Let's explore interfacing your automation with ours.

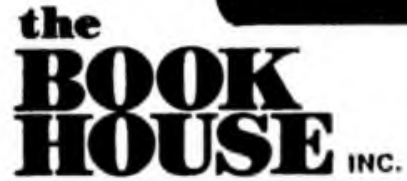

Since 1962

JOBSERS SERVING UARARIES WITH AWY BOOK IN PAINT BINCE 1962

208 WEST CHICAGO STREET

JONESVILLE, MICHIGAN 49250

INC.
6

ATOMETON

LIBRARY - VENDOR

INTERFACE

BOOK HOUSE

\section{GNY BOOK IN PBINT}

2 COMPLITS DELTERY

3 OPEN ORDAR RAPORTS

ACCURFT BOOR DHWWRY

\section{STANDLN ORDARS}

\section{Call or Write TODAY}

$1 \cdot 800 \cdot 248 \cdot 1146$

FAX: $517 \cdot 849 \cdot 9716$ 